First Peoples Child \& Family Review

An Interdisciplinary Journal Honouring the Voices, Perspectives, and Knowledges of First Peoples through Research, Critical Analyses, Stories, Standpoints and Media Reviews

\title{
Voice of a Leader: If you Truly Believe Children are our Future - the Future is Now!
}

\section{Wayne Christian}

\section{Volume 5, Number 1, 2010}

URI: https://id.erudit.org/iderudit/1069057ar

DOI: https://doi.org/10.7202/1069057ar

See table of contents

Publisher(s)

First Nations Child and Family Caring Society of Canada

ISSN

1708-489X (print)

2293-6610 (digital)

Explore this journal

Cite this article

Christian, W. (2010). Voice of a Leader: If you Truly Believe Children are our Future - the Future is Now! First Peoples Child \& Family Review, 5(1), 10-14. https://doi.org/10.7202/1069057ar

\section{Article abstract}

This paper is based on a speech by Chief Wayne Christian the Co-keynote speaker for the "Gathering and Sharing Wisdom Conference" held in Victoria BC October 6th \& th, 2010. He shares the history of his community, their children and how state policies, legislation and laws have affected a way of life for his people. He illustrates through narrative the importance of re-learning our cultural practices. Chief Christian begins his account by quoting a historical approach remembered by many Indigenous people in which the government policy of the day sought to "Kill the Indian in the Child." Chief Christian noted that First Nations people have resisted this policy, but importantly, he discussed how balance can be restored today for Indian children.
This document is protected by copyright law. Use of the services of Érudit (including reproduction) is subject to its terms and conditions, which can be viewed online.

https://apropos.erudit.org/en/users/policy-on-use/ 


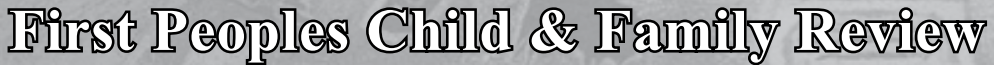

An Interdisciplinary Journal Honoring the Voices, Perspectives and Knowledges of First Peoples through Research, Critical Analyses, Stories, Standpoints and Media Reviews

Volume 5, Number 1, 2010, p. 10-14

\section{Voice of a Leader: If you Truly Believe Children are our Future - the Future is Now!}

\author{
Kulpi7 (Chief) Wayne Chistian
}

\section{Introduction}

This speech was made by Chief Wayne Christian at the "Gathering and Sharing Wisdom Conference" which took place in Victoria, British Columbia October 6th o 7 th, 2009. The original speech has been modified for publication, with an effort to maintain the narrative nature of his words. Chief Christian was invited to share the keynote space with the late Roxanne Charlie who is a young woman from his territory and has passed to the spirit world October 2009. The theme of the conference was intended to hear accounts of successful child welfare practices that have occurred in the province of $B C$. Additionally the conference organizers invited leaders to share their speaking space with young people and to model leadership with them. Reasons for inviting young people were to hear what they had to say about family and community wellness in their communities and in their post secondary and high school education. Chief Christian was invited to speak about his role in the monumental march he organized to assert their right to care for their children and families in his community. Additional footnotes have been included in this narrative to provide supplementary information, and references where required.

\section{Chief Wayne Christian}

I would like to acknowledge the Hereditary Chiefs, Chiefs and their Council members, Directors of Child Welfare Agencies, Front Line Workers, and Presenters. In addition

Questions or correspondence concerning this article may be addressed to:

Kulpi7 Chief Wayne Christian

Tribal Chairman of the Shuswap Nation Tribal Council

PO Box 460, Enderby, BC, VOE 1 VO

Email: Kukpi7 Christian@splatsin.ca

Fax: 250.838 .2131

Telephone: 250.838 .6496

\section{Abstract}

This paper is based on a speech by Chief Wayne Christian the Co-keynote speaker for the "Gathering and Sharing Wisdom Conference" held in Victoria BC October 6th \& th, 2010. He shares the history of his community, their children and how state policies, legislation and laws have affected a way of life for his people. He illustrates through narrative the importance of re-learning our cultural practices. Chief Christian begins his account by quoting a historical approach remembered by many Indigenous people in which the government policy of the day sought to "Kill the Indian in the Child." Chief Christian noted that First Nations people have resisted this policy, but importantly, he discussed how balance can be restored today for Indian children.

I would like to acknowledge Grand Chiefs, Regional Chief Members of the political executives for the Union of BC Indian Chiefs, First Nations Summit and BC Assembly of First Nations.

I want to acknowledge and give special thanks Kukstemc to the people who supported our community in 1980 with the Indian Child Caravan. What I will be speaking about today stems from the support and care you gave in 1980 when you walked alongside us for our children. I believe it is important you know who I am as your keynote speaker as it is through my experiences and stories that I speak about child welfare today.

During the sixties scoop ${ }^{1}$ my entire family of ten, five girls and five boys were apprehended by Child Welfare Services here in British Columbia. I grew up as a child in care of the government. As a young person in care, I was a victim of the state, however, today when I reflect on these experiences I see myself as a survivor of sexual and physical assault. The effects of disconnect from my family comes with much life trauma and

1. The sixties scoop was a phenomena that began during that time period, when federal responsibility of Indian children was passed over to the provinces. With this transfer came the transfer of dollars and a result of this policy was the spike in child apprehensions of Indigenous children, only to be placed with non-Native families. 
First Peoples Child \& Family Review, Volume 5, Number 1, 2010

\section{Biography of Wayne Christian:}

Kukpi7 (Chief) Wayne M. Christian, Wunuxtsin, is of Secwepemc - Sinixt ancestry. He is the proud father of seven children and fifteen grandchildren. Chief Christian was re-elected as chief of Splatsin First Nation in December 2007. He has worked for over 30 years in establishing healing and health systems for the Indigenous nations of B.C. Chief Christian was elected as tribal chairman of the Shuswap Nation Tribal Council in April 2009 and now acts as tribal spokesperson representing 10 of the 17 communities of the Secwepemc nation with responsibilities in Aboriginal title and land.

has been far reaching for myself, my family and my community. My family has experiences reflective of disconnect and isolation from family and community which has included jail for myself and more sadly, suicide for my brother on December 10, 1978. I also lost my Mother in November 1979 and I believe these are related to historical and systemic trauma and violence.

Today, I am a Father of seven children; four sons and three daughters. I am a Grandfather of fifteen children; eleven grandsons and four grand daughters. I know my children will take up the fight to protect our Nation's children and fight for our people and communities to gain recognition of sovereign title, rights and laws. Caring for our children and child welfare history in British Columbia has been affected by policies, practices and the general climate of the times related to Indigenous and white relations. Our community has responded with our own cultural practices and today I am revisiting how child welfare has either enhanced or minimized how we care for children as a Nation.

\section{Federal and Provincial Policy and Child Welfare}

In 1910 Prime Minister Wilfred Laurier was presented with a letter from our Chiefs. It was a message from our community and part of it stated the following:

"Thus they commenced to enter our "houses," or live on our "ranches." With us when a person enters our house he becomes our guest, and we must treat him hospitably as long as he shows no hostile intentions. At the same time we expect him (the settlers) to return to us equal treatment for what he receives.

Some of our Chiefs said, "These people wish to be partners with us in our country. We must, therefore, be the same as brothers to them, and live as one family. We will share equally in everything - half and half — in land, water and timber, etc. What is ours will be theirs, and what is theirs will be ours. We will help each other to be great and good." ${ }^{2}$

Although our Chiefs viewed their relations with newcomers to this land as one of mutuality, this view was not

2. The Chiefs of the Shuswap, Okanagan and Couteau Tribes of British Columbia (letter to Sir Wilfred Laurier, Premier of the Dominion of Canada August 15, 1910). shared by non-Native people during these early encounters. The approach between the government of Canada and Indigenous peoples during this time was one of assimilation and ultimately, legislative genocide. The federal and provincial government of the time made residential schools mandatory through an amendment to the Indian Act in 1920. This meant the forced and mass removal of children from their homes. Children were removed from their homes in any number of ways, including by the force of the police, Indian agents and priests. Children were transported to schools sometimes by their family members, but oftentimes in dangerous and inhumane ways; children were often transported on boats, in the backs of trucks and in cattle cars by rail. Schools were used as a mass assimilation tool with an outright goal: to kill the Indian in the child.

The Government of Canada also created laws, which forbade ceremony, such as the Potlatch Law amendment made to section three of the Indian Act in 1884, and confined First Nations people to reserves across the nation in yet another provision of the Indian Act. The Indian Act also restricted access to ancestral lands and resulted in First Nations people having no access to hunting, fishing and other subsistencebased activities. These legal restrictions to First Nations people meant no access to sacred areas of land, a relationship that was essential to maintain our culture, spirit and connection to land and community well being.

Genocide by legislation continued to evolve into a new era of national legislation, policies and law in this century, which once again has an underlying meaning: to kill the Indian in the child. For example, beginning in the late fifties and early sixties, countless numbers of Indigenous children were removed from their families and put into non-Native homes. Social workers of the time often removed children from the home because of poverty or discrimination, without evidence supporting the decision to remove the child from their home and community. ${ }^{3}$ In the fifties and sixties it was taken for granted by government social workers that Indigenous children would be better off being raised white.

For our small community these state laws had detrimental repercussions. The removal of children from our community

3 McKenzie \& Hudson, 1985. 
into white homes began a cycle of apprehensions, which continued up until 1980. In 1980 there were up to 100 Splatsin children apprehended by the state and these removals were justified as legal practices and duties under $\mathrm{BC}$ provincial law. Like many reserves in Canada our community is living in fourth world conditions in a first world country, and none of the existing child welfare policies are able to address these underlying issues of poverty, child care and living conditions. Like residential schools and the sixties scoop, although there are new or current policies regarding Indigenous child welfare, these current laws and practices are similar to policies of the 1800s albeit being flavored with new language and newly created justifications. The truth is, current policies are still a race-based response leading to assimilation, led by the federal and provincial government of Canada. That is, they are systematically and institutionally racist. Child welfare policies do not account for, or respect Indigenous child welfare practices. Social workers often hold racist ideologies and Indigenous children continue to be overrepresented in the child welfare system, often disconnected from their families and communities, and these realities contribute to ongoing intergenerational traumas that impact the lives of all Indigenous People. Regardless of questionably positive policy intentions they all have the same effect: to kill the Indian in the child. The impact of all of these historical policies has left our families and communities affected by the multi generational effects of historical colonial trauma.

\section{Traditional Child Welfare Laws and Policy}

In 1980 Splatsin enacted laws based on our traditions and how we looked after each other. In 1979 to 1980, we viewed our legislation clause-by-clause. In our analysis we reviewed what practices, policies and laws worked for our people in the past. Our population was 350 at that time. We found that every family with the exception of two families were impacted and affected by the sixties scoop. Over one hundred children were stolen from the embrace of their grandmothers and mothers, which in my view is the second wave of genocide, following residential school. It has been twenty-eight years since we have enacted laws and jurisdiction that works for and reflects our community and our children. Today our population is 800 and for the last twenty eight years 450 children have been living within our community and under our traditional laws which has resulted in less than 5\% of our children going into care, even within our own legislated system. It was necessary for our community to strategize laws that reflect our customs. To date in $\mathrm{BC}$, there are no other Indigenous Nations who have sovereign child welfare jurisdiction for their own laws, own customs, and their own families like us, the Splatsin Nation. Hence, Splatsin Nation represents a unique example of a community that was able to reclaim the right and responsibility of child welfare, providing a successful example of a Nation that has found a way to support children and families outside of harmful governmental policies.

\section{Traditional Healing Approaches}

\section{The Role of Culture and Traditions}

McCormick ${ }^{4}$ conducted a comprehensive study examining the healing processes of Indigenous people in British Columbia, finding that traditional healing approaches were both popular and powerful. Study participants identified a number of traditional healing practices including: participation in ceremony, expression of emotion, learning from a role model, establishing a connection with nature, exercise, involvement in challenging activities, establishing a social connection, gaining an understanding of the problem, establishing a spiritual connection, obtaining help/support from others, self care, setting goals, anchoring self in tradition, and helping others. ${ }^{5}$

Research conducted in British Columbia on Aboriginal strengths found that Aboriginal wellness and strength could be found in several areas including: a sense of community, Aboriginal identity and cultural traditions, contributing to others spirituality, and living in a good way and coming through the hardship many families and communities face. ${ }^{6}$ These studies all demonstrate the importance of identity and cultural healing practices in positive healing outcomes for Indigenous People, and a return to these practices as western models continue to exclude and fail Indigenous Peoples. This healing leads in turn to a sense of empowerment for Indigenous People?

It has been observed by some that many traditional healing practices have been eroded over time, with colonialism causing a reduction in spiritual practices and traditional herbal medicine usage. ${ }^{8}$ This was further impacted by the Indian Act restrictions on a number of cultural ceremonies and practices, related in part, to a fear of settler conversion to Indigenous practices. It is important to note that while many practices have been impacted by colonial interference, these practices are not entirely lost. ${ }^{10}$ In fact, there is a resurgence of these practices in many instances. For example, in a study of residential school survivors in the Cariboo region of British Columbial 1 "researchers found that $45 \%$ of those surveyed consulted elders for advice and $41 \%$ accessed the sweat lodge ceremony

\footnotetext{
4. 1996.

5. McCormick, 1996.

6. Van Uchelen, Davidson, Quressette, Brasfield \& Demeris, 1997.

7. McCormick, 1996.

8. Warry, 1993, as cited in McCormick \& Wong, 2006.

9. McCormick \& Wong, 2006

10. McCormick \& Wong, 2006

11. Cariboo Tribal Council, 1991, as cited in Wyrostok \& Paulson, 2000.
} 
as part of their use of mental health services. Two-thirds of respondents endorsed traditional Native healing as

a mental health resource"."2 In a 1991 study involving 500 Aboriginal addiction-counsellor trainees it was found that $27 \%$ used Aboriginal healing activities as an integral part of their own healing. ${ }^{13}$ In a study of traditional healing practices among Aboriginal students, it was also documented that the majority of participants reported as having participated in a variety of traditional healing approaches.

\section{The role of the family and community}

It is important for Indigenous People to receive support from others, including their friends, the family, and the community both socially and in support-specific interactions. For Indigenous People there is a shared responsibility among families and communities to ensure the wellbeing of others. ${ }^{14}$

\section{The role of spirituality}

Because an Indigenous world-view sees spirituality and healing as interconnected, spiritual beliefs and practices are important in the healing process. Because spirituality is an important aspect of many elements of Indigenous identity, an integrated approach to healing that includes spirituality helps to create positive outcomes for Indigenous People. These spiritual elements can include the sweat lodge, a relationship with the Creator, plant medicines, drumming, the medicine wheel and numerous other manifestations. ${ }^{15}$

\section{The fusion of western and traditional approaches to healing}

In a review of successful healing programs for Aboriginal people it was found that such programs stressed "traditional values, spirituality, and activities that enhanced self-esteem.16 While Indigenous approaches to healing are largely successful on their own, it has been argued that using these approaches in conjunction with, or fused into western healing practices, can create other new healing approaches, and make combined healing approaches both more effective and more applicable to Indigenous Peoples. ${ }^{17}$ While Indigenous approaches have been historically rejected by western practitioners, learning about and respectfully incorporating Indigenous healing perspectives into these approaches is being both explored and advocated for. ${ }^{18}$

\footnotetext{
12. Wyrostok \& Paulson, 2000, p. 16.

13. Nechi Institute on Alcohol and Drug Education Research Centre, 1991 as cited in Wyrostok \& Paulson, 2000.

14. Ross, 1992, as cited in McCormick \& Wong, 2006.

15. Kirmayer, Simpson \& Cargo, 2003.

16. McCormick, 2000, p.29.

17. Anderson, 1992, as cited in McCormick, 2007.

18. Sue \& Sue, 1990.

(C) Chief Wayne Christian
}

\section{In Closing}

What does the future hold for our children and communities? Our laws, our traditions, our culture, our future-culture is cultural treatment to heal from the attempts of genocide by the state. First and foremost I ask each of you, how does one create safety for our children, for our parents and for every segment of our communities? First, as helpers and leaders in our communities we need to seek to understand how to build a cognitive life raft for our people. We need to invest in the children and stop child abuse. We need to utilize our traditions to re-build our Nations by creating puberty rites on how boys become men and how girls become women. We need to learn how to acknowledge our relationship to the land; the land is our culture; the land is the ashes of our Ancestors; the land provides all that we require from cradle to grave. Of worldview of balance including the four directions; four races of the world and interconnectedness not integration. All research programs have to be built on our Cultural values and traditions but most importantly on our traditional laws.

We must all re-invest in our children if the policy of government was to "kill the Indian in the child" then our policy is to "bring back to life the Indian in the child". If you truly believe that the children are our future then our future is now! 20 years ago we had a population of 350 Secwepemc people. Today our population is 800 .

Decisions or lack of decisions by us as helpers and leaders do effect the next seven generations. I am asking each one of you to understand that you can make a difference if you help one person no matter what race or economic situation; you will move closer to truly reducing harm to mankind. I invite you to join hands together in our journey of healing. We need your help in the fight against the colonial laws and structures that continually deny that we exist and who deny us OUR HUMAN RIGHTS to our land. We must stand each other up to be great and good, we must stand up our relations, all our relations, the birds, animals, water, the plants, the fish, and the earth.

Actions speak louder than words. Leadership is action not a position. If you truly believe that the children are our future, then the future is now. If the state said "kill the Indian in the child" then our job is to "bring back to life the Indian in the child".

All my relations, Chief Wayne Christian. 


\section{If you Truly Believe Children are our Future - The Time is Now!}

\section{References}

Kirmayer, L., Simpson, C., \& Cargo, M. (2003). Healing traditions: Culture, community and mental health promotion with Canadian Aboriginal Peoples. Australian Psychiatry, 15-23.

McCormick, R. (1996). Culturally appropriate means and ends of counselling as described by the First Nations People of British Columbia. International Journal for the Advancement of Counselling, 18, 163-172.

McCormick, R. (2007). Aboriginal traditions in the treatment of substance abuse. Canadian Journal of Counselling, 34(1), 25-32.

McCormick, R., \& Wong, P. T. P. (2006). Adjustment and coping in Aboriginal People. In International and Cultural Psychology, Paul T. P. Wong and Lilian C. J. Wong (Eds.). New York: Springer.

McKenzie, B., \& Hudson, P. (1985). Native children, child welfare, and the colonization of Native People. In The Challenge of Child Welfare, K.L. Levitt \& B. Wharf(Eds.). Vancouver: UBC Press.

Sue, D. W., \& Sue, D. (1990). Counselling the culturally different: Theory and Practice. Toronto: John Wiley \& Sons.

Van Uchelen, C. P., Davidson, S. F., Quressette, S. V. A., Brasfield, C. R., \& Demerais, L. H. (1997). What makes us strong: Urban Aboriginal perspectives on wellness and strength. Journal of Community Mental Health, 16(2), 37-50.

Warry, W. (1998). Unfinished dreams: Community healing and the reality of Aboriginal self-government. Toronto: University of Toronto Press.

Wyrostok, N. C., \& Paulson, B. L. (2000). Traditional healing practices among First Nations Students. Canadian Journal of Counselling, 34(1), 14-24. 